\title{
Shifting Up and Back
}

The European Turn in Canadian Refugee Policy

Dagmar Soennecken

CMS 2 (1):101-122

DOI: 10.5117/CMS2014.1.SOEN

\begin{abstract}
During the last decade, Canada's immigration and citizenship policies have been radically transformed. Hardly any aspect has been left untouched. That humanitarian migration has also been restricted and transformed has generally been linked to the worldwide "securitization" of migration. This paper argues that the timing and character of a number of key changes also represent a European turn of Canada's refugee policy, which has seen Canada change from a policy innovator and humanitarian leader to a student, follower and adaptor of a key set of restrictionist asylum policies practiced in Europe.
\end{abstract}

Keywords: refugee determinations, Canada, Europe, Europeanization, venue shopping, safe third country, safe country of origin

\section{Introduction}

During the last decade, Canada's immigration and citizenship policies have been radically transformed. Aside from the reforms that culminated in the 2001 Immigration and Refugee Protection Act (IRPA), the last four years (2008 to 2012) have been particularly intense. Changes have been made to all three permanent immigration streams -family reunification, economic and humanitarian migration, as well as to citizenship and settlement policies (Alboim \& Cohl October 2012), with even further announced changes soon to come. On the whole, this transformation has been interpreted as Canada tightening and restructuring its policies to remain competitive 
in the globalized, economic "battle for the brains" (Shachar 2006), in the process excluding those who do not fit the neoliberal logic (Varsanyi 2008).

That humanitarian migration has also been restricted and transformed has generally been linked to the worldwide "securitization" of migration (Dauvergne 2008; Watson 2009). While that is certainly correct, this paper will show that the timing and character of a number of key changes also represent a European turn in Canada's refugee policy, which has seen Canada go from a policy innovator and humanitarian leader (whose people were awarded the United Nations High Commissioner for Refugees,' UNHCR) Nansen medal in 1986, "in recognition of their essential and constant contribution to the cause of refugees within their country and around the world"z) to a student, follower and adaptor of a key set of restrictionist asylum policies practiced in Europe - most notably the Dublin agreement (which restricts freedom of movement for asylum seekers by preventing them from filing an asylum claim in their country of choice or in more than one state) and the "safe country of origin" list. ${ }^{3}$ Applicants from countries on the latter list are deemed to not ordinarily generate refugees and as a result, their claims are assessed in an accelerated fashion, with tight procedural timelines and few appeal options.

To understand this evolution, I draw on one of the most prominent explanations regarding the way in which migration controls have tended to grow. The "venue shopping" explanation views the Europeanization of refugee policy as a side-effect of embattled nation states that are looking for the most favourable venue for their preferred policy outcomes - tighter migration controls. In the process, they shift control "up" to the intergovernmental and "down" to the local level, as well as "out" to private (non-state) actors - all in order to evade the growing significance of rights based regimes at the international and domestic level (Guiraudon 2000). Although this explanation is widely regarded as seminal even more than ten years later (Kaunert \& Léonard 2012), most of the empirical research has thus far tended to focus on Europe. ${ }^{4}$

The Canadian case demonstrates that a state, once it adopts a migration control paradigm, may employ similar techniques to those used by other advanced industrialized states even though, objectively speaking, it is relatively less restrained or "threatened" by the courts and rights-based politics than other states (Anderson 2010: 942). The European turn in Canada's refugee policy is thus an example of a state seeking more favourable policy outcomes by shifting policy "up" to the intergovernmental level and interestingly, also "back" to the executive level. The changes overall represent a regression or return to the backbone of Canadian humanitarianism: namely 
executive control and discretion, with a hefty dose of bilateralism that ironically, represents a significant loss of control.

As we shall see, Canada is a latecomer to the securitarian world, having only joined the "control" club of nations in the 1990s. Although it tried to shift control "upwards" early on by, for instance, laying the groundwork for a safe third country agreement with the U.S. in the late 1980s, not only did the provisions prove controversial domestically (Abell 1997) but achieving such an agreement drew little interest on the US side and was thus not actually forged until after $9 / 11$, when both countries' positions had aligned, demonstrating that we need to pay attention to timing and sequencing when studying policy. Actors cannot change their institutional environment at will even though the paradigm may have shifted. They need to wait for a critical juncture to arise before they can do so (Guiraudon 2000: 258; Pierson 2000).

Overall, the comparison between the two sides of the Atlantic underlines that the similarities we find are not simply instances of uni-directional policy learning or borrowing. Although there is sufficient evidence to suggest that a number of the recent changes to Canada's refugee policy were directly inspired by events in the EU, and indeed by EU policy changes (Abell 1997; Macklin 2005), the causal story for these changes is unquestionably more complex. Instead, as Thouez and Channac suggest, the changes should be conceptualized as cases from the "policy transfer continuum," which involves multiple actors, ideas and institutional arrangements and range from mere lesson drawing to coercive transfers (Thouez \& Channac 2006). This multifaceted understanding of policy transfers further places more emphasis on the transmission of knowledge, ideas and possibilities than on policy choices.

The reminder of the article is organized as follows. The next section opens with a select review of the venue shifting argument as it applies in the European case before moving onto the analysis of the Canadian changes. For space reasons, the comparison is centered on the shift "up" to the intergovernmental level in both regions. The European section begins by reviewing the key role of inter- and transgovernmental actors in the shaping of Europe's common asylum "control" policy. Next, I briefly discuss perhaps the cornerstone achievement of their collaborative efforts - the safe third country or "Dublin" system, which came into effect in the European Union (EU) in 1997. Since it was introduced quite some time ago, the discussion includes a summary of critiques and shortcomings of the system. The European section closes with a brief review of a related and widely popular asylum control measure that has not (yet) been "up" shifted (not 
to mention "communitarized"5) - the designated/safe countries of origin (SCO/DCO) list.

The Canadian section begins by discussing Canada's "long-standing outlier" status before surveying the larger discursive and normative shifts from the mid-80s to the 1990s, which saw Canadian bureaucrats and politicians abandon the "protectionist" paradigm and finally embrace the prevailing security and control focus of the international migration policy community. This shift made possible the adoption of certain policies "that were previously deemed inappropriate under the protection paradigm" (Irvine 2011). Chief among them were legislative amendments (debated between 1988 and 1992) that eventually lead to the 2001 US-Canada Safe Third Country Agreement (STCA), which was modeled on the "Dublin" agreement and is discussed next. Third, the Canadian paradigm shift also opened the door for other policies previously unacceptable that would accelerate the hearing of certain refugee claims, which were deemed "manifestly unfounded" from the start. In this context, the last part of the Canadian section discusses the introduction of "designated country of origin" list in late 2012. This idea, widely found in Europe, was first put into law in Switzerland in 1990. All in all, my goal here is not to provide a detailed analysis of Canada vs. Europe but to show that outwardly similar choices in policies and venues, once planted in very different soil, are not likely to generate similar outcomes because of the constraining culture of existing ideas, interests and institutions.

\section{Up-shifting and the Europeanization of asylum policy}

The prevalent venue-shifting thesis argues that European migration and asylum policies in place today are the outcome not of EU policy initiatives, but rather of "vertical" or transnational co-operation between law and order officials subscribing to a migration control paradigm that began in the late 1970 s to mid-1980s. Briefly, co-operation occurred because political actors sought new venues to maximize "control"-focused policy outcomes in light of growing constraints at the domestic level, in particular through legal norms and court rulings but also through NGO pressure and political compromises (Guiraudon 2000). Although EU institutions, legal norms and political bargaining eventually populated these vertical spaces and the EU formally committed to the creation of a common asylum policy with the 1997 Treaty of Amsterdam, the history of these networks, their membership, mode of operation and goals left an imprint on the institutional set-up 
and policy options subsequently being pursued and ultimately controlled the rules of the game (Lavenex 2001). For instance, the European Court of Justice (ECJ) has long been kept away from reviewing migration and asylum policies. Similarly, the role of EU Parliament, generally perceived as friendlier toward migrants, has been strengthened only quite recently. Finally, it took NGOs a number of years until they built their own networks and access points to the EU officials and their policy-making apparatus relating to migration (Guiraudon 2001).

In the European context, national policies have generally been referred to as "Europeanized" when they are affected by the processes of EU integration, which is the political and economic coming together of participating member states in Europe (Olsen 2002). More specifically, Europeanization can occur either in a "bottom-up" or a "top-down" fashion, i.e. either the European level transforms domestic policies or member states are able to 'upload' their domestic policy preferences to the EU level and thereby shape EU policy (Graziano \& Vink 2007). Interestingly, it has been formally extended to other countries beyond the EU member states, in particular for the purposes of controlling migration (Lavenex 1999). Some scholars argue that the process has further created a "European" style of governance, i.e. a set of beliefs, norms and identities, not to mention complex institutions and decision-making procedures (Lavenex 2001: 852). All in all, EU integration has been predominantly understood as a set of advances achieved primarily through intergovernmentalism, whereby powerful member states try to realize their policy preferences through bargaining and negotiation with one another at the EU level (Moravcsik 1998), although other scholars argue that the involvement of the EU's supranational actors in one sector generates a momentum (or "spill-over") that will lead to further integration of others (Guiraudon 2000).

In the area of immigration and asylum policy, Europeanization has been particularly late, slow in the coming and fraught with difficulties. Reluctance to give up control and state sovereignty assertions have been higher than in other policy areas. Although EU member states first formally committed to the establishment of a "Common European Asylum System" (CEAS) with the 1997 Treaty of Amsterdam (in force 1999) and the 1999 Tampere summit, the origins and direction of Europe's now common asylum policies, as key contributions by Guiraudon and Lavenex have shown, are in fact much older and have been much more strongly determined by informal, opaque mechanisms of intergovernmental and transnational co-operation among 'clubs,' such as the 1975 TREVI group, which involved a network of 
law enforcement and government bureaucrats across Europe collaborating to address cross-border terrorism (Guiraudon 2000: 254; Lavenex 2001).

During the second half of the 1970 s and throughout the 1980 , a wide network of similar groups sprang up ranging from task forces and regional working groups to ad hoc committees (Thouez \& Channac 2006). All blended asylum with border control, policing and crime prevention. These transnational networks have transformed into a multilevel governance regime and the domestic agendas of political players involved have been the driving force behind some of the EU's key migration control policies, notably the "country of first asylum" provisions that first accompanied the 1985 Schengen "open borders" agreement and which later became the 1990 Dublin "I" Convention already referred to earlier (Guiraudon 2000).

This co-operation or shift "up" to the intergovernmental and transnational level was attractive because these venues were until quite recently fairly void of enforceable human rights norms and political debate with regard to migration. Humanitarianism and human rights norms more generally have only very recently entered the debate at the EU level, having long been kept at bay by any absence of reference to them in the EU treaties more generally and through (at first) the deliberate exclusion of the European Court of Justice (ECJ) from reviewing immigration and asylum policy more specifically (Guild 2006). Guild further notes that the initial exclusion of any rights for refugees at the EU level - despite the ratification of the Geneva Convention for Refugees by all member states - was not an oversight but a deliberate choice based on what she calls a profound "antipathy" and "hostility" towards asylum seekers. Therefore, she adds, if refugees have been present in EU rules and norms, they have thus far been only objects or passive bodies (Guild 2006: 633-636).

Only with the 2009 Treaty of Lisbon has the EU finally committed itself to making the EU Charter of Rights binding EU law and decided to formally accede to the 1950 EU Convention of Human Rights (ECHR), both measures, which will expand the ECJ's oversight over the murky area of "freedom, security and justice," to which asylum policy was assigned (Carrera, De Somer, \& Petkova 2012). These changes, together with the steadily growing influence and jurisprudence of the European Court of Human Rights (EUCtHR), have lead to a steadily growing judicialization of asylum policy (Kaunert \& Léonard 2012:1409). This judicialization, together with a growing communitarization of EU asylum policy, whereby the EU Commission puts items on the agenda, which are then discussed and debated in the EU Council and consented to by the EU Parliament, represent the most 
significant constraints on the "venue shopping" ability of EU policy makers going forward.

However, thus far, policy-making through the communitarian method has been slow and difficult. So far, three key directives and one important regulation have been passed through the 'community' method: ${ }^{6}$ the 2003 Reception Conditions, 2004 Qualification and 2005 Asylum Procedures Directive as well as the 2003 Dublin (II) Regulation. After an evaluation process, amendments to all three directives and the Dublin II Regulation were proposed in 2008 (so called "recastings") and a related directive - the 2008 Returns Directive - was also passed. However, amendments to the older directives and the Dublin II regulation were stalled for a long time and the majority have not been successfully passed yet, illustrating the sluggish and challenging process of the formal, 'community' method of Europeanization. ${ }^{7}$ At the same time, the directives have been criticized for institutionalizing only the least common denominator, furthering the entrenchment of "fortress Europe."

\section{Up and out: the Dublin system}

The 2003 Dublin "II" system grew out of the 1990 Dublin "I" regulation, which was preceded by an even older version developed by Denmark in 1986 (Costello 2005: 40) and until 2013 determined EU-wide the country responsible for processing an asylum application based on the idea that an asylum seeker is not entitled to seek out (or "shop for") the country in which they intend to reside but should claim asylum in only one country - namely the first, "safe" country." What is remarkable about this system is how few of Europe's asylum seekers it affects and how poorly it has worked. Yet it still remains in operation..$^{10}$ Existing court decisions and proposed changes thus far merely tinker with operational details of the system but have not questioned its basic rationale, even though it has been referred to as "an expensive waste of time" by some legal experts (Peers 2011: 362 ). Basically, despite claims to the contrary, it prolongs the time period during which refugees remain "in orbit" i.e. without status and even prevents some from filing a claim altogether, consumes considerable bureaucratic resources and in the end, does not lead to all that many transfers. Refugee advocates further note that it has also increased the practice of detentions in the EU and exacerbated the problems with refugee determinations in certain border countries, like Greece, that were already considered not to be a "safe" country by some human rights observers. ${ }^{11}$ 
These problems have been partly acknowledged by the EU Commission, which proposed a revised version of a number of asylum-related regulations, including of the Dublin and EURODAC regulations in 2008 and 2009, ${ }^{12}$ which made only slow progress. In 2011, an amended proposal to Procedures Directive was tabled, which contains revisions relating to the safe country concept. ${ }^{13}$ The EU Parliament, which is now a full co-legislator (through the formerly "co-decision", now “ordinary" legislative procedure), also supported calls for a revision (but not abolition) of the safe third country concept. Most recently, a number of court cases by both, the EUCtHR and the ECJ, acknowledged the problems with operationalizing the safe third country concept, and criticized the dysfunctional nature of the Greek asylum system in particular, which was widely regarded as violating human rights standards. The courts ruled that member states who continue to send refugees back to Greece were violating the EU's Human Rights Convention (Carrera et al. 2012). ${ }^{14}$ The ECJ further underlined the need for a regular assessment of the actual human rights conditions in a third country, demonstrating that court decisions are unlikely to completely undo policy instruments that are the outcome of prior "vertical" policy-making, such as the Dublin system.

\section{An incomplete shift? Safe countries of origin lists}

A concept related to the "safe third" country idea, which is the basis for the Dublin system, is the notion of a "safe country of origin." This concept assumes that not all countries around the world ordinarily generate refugees - as judged based on various criteria ranging from their democratic to their human rights practices - and that claims for protection from those countries are therefore most likely unfounded and can be processed in an accelerated fashion, with fewer procedural safeguards. It was first put into asylum law in Switzerland in 1990 and was subsequently adopted by a wide range of EU member states (Costello 2005; Gurzu 2012). However, in contrast to the Dublin system, the safe country of origin concept has not yet been incorporated into EU law, although negotiations are ongoing. Interestingly, a number of EU states, among them Poland and Sweden, do not use such lists at all.

Although the 1992 London resolutions already endorsed the SCO concept in principle, ${ }^{15}$ the first formal push for the mandatory establishment of an EU-wide list came only in 2003 through a proposal from Austria - roughly a decade after many EU states had began operating their own, national-level lists. Peers notes that the real push at that time stemmed from "a group of 
interior ministry civil servants" trying to control the development of the EU's Justice and Home Affairs (JHA) policy by holding private meetings. ${ }^{16}$ While these meetings are certainly evidence that political actors have tried to "up" shift and control the creation of EU-wide SCO lists in a fashion similar to the past, the fact that no such lists exist yet opens up intriguing questions regarding the venue shifting process in practice.

As Gurzu reports, although a preliminary list of countries was subsequently published as part of a draft Commission directive in 2004, negotiations revealed continuing disagreement among member states. Even countries with strong migration control preferences, like Germany, France and the UK objected to some of the country designations, which shows that there is more at play than more powerful member states failing to impose their policy preferences on weaker ones. But alternatively, the more powerful member states also do not seem to be content with leaving the SCOs at the national level, so it is likely too early to judge. The fact that states without such lists were unwilling to participate in these negotiations certainly indicates that an EU-wide solution will eventually be reached (Gurzu 2012).

Considering that a number of national courts have already ruled on the concept over time, though with varying results, the incentive to "up" shift the SCO list to the EU level certainly exists. A Belgian court ruled it unconstitutional in 1993. The Belgian government only successfully reintroduced such a list in 2012, a few years after the 2005 EU Procedures Directive endorsed the possibility of an SCO list. ${ }^{17}$ The German Constitutional Court had declared the practice of such lists constitutional back in 1996. A UK court struck down the designation of Pakistan as an SCO in 2001, although courts have upheld the designation of India as an SCO (Costello 2005: 51). In 2012, the French Conseil D'Etat ruled unconstitutional the addition of Kosovo and Albania to the French list, two countries also on Belgium's list of (presently) seven such countries. ${ }^{18}$ Finally, the initial exclusion of the EU Parliament from the drafting of an EU-wide SCO list lead the ECJ to enter the fray and mandate its inclusion in a 2008 ruling (Gurzu 2012: 8), which promises to prolong the negotiation process. To sum up, although some of these judicial rulings certainly constrain national governments, their divergence reflects the different practices and opinions at the national level more generally but do not prevent the creation of EU-wide lists. Discussions are still ongoing and need to be closely observed in the future. So far, the delay and disagreement over the "up" shifting of the SCO lists to the EU level serve as an interesting contrast to the history of the Dublin or "safe third country" agreement. 


\section{The European "turn" in Canadian refugee policy}

While the story of venue-shifting in Europe is very much driven by political actors choosing inter- or transgovernmental venues to avoid legal and political constraints in achieving control-centered migration policy outcomes, Canada was long considered a proponent of a "protectionist" paradigm, which translated to it being considered a "control laggard" by others.

Canada's "outlier" status manifests itself along three primary axes: First, Canada's inland refugee recognition system has been called "a model to be emulated" by UNHCR (Anderson 2010: 940). This is reflected in the fact that the primary body for determining inland refugee claims in Canada, the Immigration and Refugee Board (IRB) has consistently had the highest Geneva Convention recognition rate amongst advanced industrialized countries, typically ranging between 40 and 50 percent, while the average European recognition rate was only 20 percent (Dauvergne 2005: 123) $\cdot{ }^{19}$ Second, under the Convention, the IRB has frequently interpreted the definition of a refugee expansively and lead the way internationally in policy development (e.g. by drafting guidelines regarding the recognition of gender-based persecution in 1993). Third, in addition to its inland determination system, Canada also operates an overseas resettlement program for refugees and others at risk that is relatively large considering its population. ${ }^{20}$ Although still smaller than the inland counterpart, it is further notable, as Dauvergne observes, that the overseas program consists of both a government and a privately sponsored stream (Dauvergne 2005). ${ }^{21}$

Given this reputation, the details and timing of Canada's transformation are particularly interesting. Researchers have identified the 1980 os and the 1990 as the critical period in this regard. The 1980 s are frequently heralded as the height of the protectionist paradigm, with the 1985 Singh decision (which granted refugee claimants physically present in Canada protection under and access to the 1982 Charter of Rights and Freedoms and mandated an oral hearing) often serving as a corner-stone because it was followed by a fundamental re-design of the refugee determination procedure that created an independent and quasi-judicial tribunal, the IRB, which became the main agency for overseeing refugee claims in Canada (Kelley \& Trebilcock 1998).

Yet the 1980 also saw a number of perceived refugee "crises" lead to refugee policy becoming the subject of an intense and increasingly partisan dispute (Abu-Laban 1998:191). In the late 1980s and early 1990s a new political party, Reform, rose in political power, which put immigration on the agenda for the 1993 election and, as Abu Laban notes, broke up the existing 
elite consensus over immigration policy by opposing certain kinds of immigration (Abu-Laban 1998: 195). In response, the government tightened some policy aspects and slowly began to shift to a more 'securitarian' paradigm (Watson 2009). For instance, in 1988, the Canadian Immigration Act was amended to allow the government to designate certain countries as "safe" for the purposes of refugee determinations. However, there were discussions as to whether the United States could be considered "safe," in particular because of the influence of U.S. foreign policy on refugee determinations involving Latin America. American law-makers at the time were also not particularly interested in incurring further costs on their side of the border. As a result, the provision was not implemented by cabinet at the time (Abell 1997: 575), i.e. no country was declared "safe" until 2004 (when the 2001 agreement came into force).

Still, the 1990s were critical in that they brought about a larger discursive shift towards securitization in Canada that was reflected in media coverage and in public opinion (Watson 2009). Anderson connects these securitizing moves to a much older and larger 'control/rights' struggle that he traces to Parliamentary debates over the nature of Canadian liberalism and democracy as far back as Confederation (Anderson 2010). Irvine details the critical role that immigration officials played in shifting Canada towards the "security-control" paradigm in the 199os (Irvine 2011).

Although these officials became "transnationally active" in the same networks of bureaucrats and officials detailed by the European literature discussed earlier, they did not initially take a restrictionist stance when beginning to participate in these networks. However, officials gradually absorbed the security/control-centric discourse of their colleagues, especially when Canadian officials increased their participation in the 1990s. In the process, their views of Canada shifted from regarding it as a humanitarian leader to an outlier of a different sort - namely a "victim of increasing migration flows" and a control laggard, with a refugee system open to abuse. Eventually officials passed on the more 'securitarian' view already dominant in other countries, in particular Europe, when briefing politicians (Irvine 2011).

On the policy front, Canada's larger immigration policy became increasingly subject to neoliberalist influences from the 199os onward leading to a substantial shift in focus from family reunification to the economic value of immigrants. This resulted in an increased role on the part of the Canadian provinces in determining a significant share of these immigrants (Dobrowolsky 2011: 117). Despite all this, remarkably, the 'mechanics' of Canada's inland refugee determination system remained relatively unscathed until 
2001. Changes to Canada's refugee policy at this time occurred largely by "remote control," namely through the increasing use of interdiction measures and the posting of immigration officers overseas (Kernerman 2008).

Aside from some reforms in 1992-93, perhaps the most notable development at this time was a 1997 government commissioned report that proposed a dramatic reorganization to Canada's refugee policy and determination system, including the creation of a merged unit for assessing overseas and inland refugee claimants staffed entirely by civil servants (Review 1997: 77). Encountering heavy public criticism, it did not however result in any reforms (Kelley \& Trebilcock 1998).

Worth highlighting separately is Canada's response to yet another perceived "crisis," namely the arrival of a substantial number of Roma from the Czech Republic in 1997 (almost all of whom were granted refugee status in Canada), because it symbolizes the government's growing attempts to "manage" the expansive IRB practices. First, the government imposed a visa requirement on Czech citizens, another classic "remote control" tool used to reduce the influx of unwanted migrants since the late 1970s (Dirks 1995), and second, it drew on a rarely used discretionary power to intervene in the practices of the IRB. This intervention entailed encouraging the IRB to establish a "lead case" practice by which government officials supplied additional information to the IRB for them to more efficiently adjudicate large numbers of similar cases. This practice was then used to adjudicate cases for a number of Roma subsequently arriving from Hungary. As a result, success rates for the latter claims plummeted (Kernerman 2008: 246). In a subsequent court challenge, critics argued that the government (more precisely, the Minister of Citizenship and Immigration) tried to influence the outcome of such cases by encouraging this process. Eventually, the Federal Court ruled that this particular practice violated the independence of the IRB members but noted this did not prevent the IRB more generally from developing tools to more efficiently manage its case load. ${ }^{22}$ Even in Canada, where gaining access to the courts has been historically quite difficult for refugees and any ability to have the merits of the case reassessed has been formally unavailable until reforms in 2012, this example shows that government policy is not immune from judicial scrutiny. In fact, the Supreme Court of Canada, in particular, is regularly blamed for having "gummed up" the refugee determination process to the extent that access to judicial review is now considered problematic and even suspect. ${ }^{23}$

The most important reforms to Canada's refugee policy prior to the ones passed in the last four years though came arguably around 9/11, namely with the passing of the 2001 Immigration and Refugee Protection Act, 
which was already drafted prior to attacks on the World Trade Centre. Although the legislation (again) left the fundamental 'mechanics' of the IRB essentially intact, it significantly expanded inadmissibility rules and strengthened detention, deportation, and interdiction provisions. Together, they furthered Canada's shift towards securitization and ensured that more and more would-be refugees either could not reach Canada or were excluded from the procedure at the outset (Jimenez \& Crépeau, 2002). ${ }^{24}$ The most important institutional change concerning refugee determinations - the creation of a Refugee Appeals Division (RAD) at the IRB, which is now (only since December 2012) in charge of overseeing an administrative appeal on the merits of the case - was initially delayed for a number of years. In return for the establishment of the RAD, refugee advocates reportedly supported a reduction in the number of IRB members who would be hearing a case from a panel of two to a single member (Soennecken 2013b).

Over the decades, Canada's refugee policy has been regularly denounced as too "liberal" by domestic conservative critics (Stoffman 2002) and international observers alike, in particular after $9 / 11$ when the differences between the Canadian and U.S. refugee policies attracted the attention of U.S. academics and law-makers (Forest 2006: 62). Yet it was not until the mid-199os that Canadian policy makers joined the "club" of like-minded, security and control focused states and subsequently began to align not just their outlook but also their policies with those states.

\section{6. “From Dublin with love:" The Canada-US Safe Third Country Agreement (STCA)}

Most importantly for our purposes, Canada and the United States finally entered into a "safe third country" agreement in December 2001. This bilateral agreement was part of a much broader and more comprehensive "Smart Border Action Plan" following the events of $9 / 11$, that included a focus on the establishment of a "security perimeter" through securitization of not only the flow of people and goods, but also infrastructure, plus a commitment to coordination and information-sharing (Brunet-Jailly 2006; Salter 2007). The STCA was a key component of this plan but did not come into force until Nov 2004. Visa harmonization was also one of the goals (Macklin 2005). The "smart border" plan was further expanded with the recent "Beyond the Border Action Plan," released in 2011. ${ }^{25}$

At present, the Canada-U.S. STCA only applies to refugee claims made at the land border. ${ }^{26}$ In a similar manner to the Dublin system, claimants 
who have previously been in the U.S. are essentially prevented from filing a claim in Canada. The portion of Canada's refugee claims made at the Canada-U.S. border has traditionally been substantial - from 2002 to 2004 it was around 32 percent of yearly inland claims (Canada 2006). ${ }^{27}$ Aside from appeasing U.S. security concerns, the primary motivation for Canada to conclude the agreement was clearly therefore to reduce the number of claims (Arbel 2013).$^{28}$ Government figures show a drop of 55 percent in applications at the Canadian end from 2004 to 2005 , the first year the agreement was implemented. ${ }^{29}$

However, as with the Dublin Convention, the few figures publicly available further indicate there is a significant gap between the number of claims screened and the number actually returned. The primary reason for this gap is the large number of claimants who qualify for an exception under the agreement.$^{30}$ In 2005, 80 percent of claims made at the border qualified for such an exception (3254 out of 4033 total claims). Only 303 or 13 percent did not..$^{31}$ Of those qualifying for an exception under Canadian rules in 2005, a little fewer than half were exempt based on family ties $^{32}$, while the bulk of the remainder (37 percent) were exempt based on a criterion that is non-existent under the Dublin Convention - namely that applicants were nationals of a country to which Canada had temporarily suspended removal orders due to, for instance, war or an environmental disaster, e.g. as in Afghanistan, the Democratic Republic of Congo, Haiti, Iraq and Zimbabwe. ${ }^{33}$ This STCA exemption was removed in 2009 - an action cited as being "another step toward improving Canada's asylum system," ${ }^{44}$ although it is hard to deny that numbers must have played a role in this decision. While this will lead to a further reduction in claims at the Canadian border, the more notable effect of such agreements may be their power of deterrence, although this is difficult to ascertain..$^{35}$

Although the conclusion of the Canada-U.S. STCA agreement is certainly an example of "outward" shifting on behalf of the Canadian government, the substantial delay between the adoption of the 1988 enabling provisions and the conclusion of the agreement in 2001 (which did not come into force until 2004) illustrates how, political actors interested in migration control needed to wait for a critical juncture before changing public policy. Moreover, the Canadian case remains a bilateral agreement that, although unsuccessfully challenged in principle before the Canadian courts, ${ }^{36}$ is not likely to be encroached upon by legal norms or political controversy due to the lack of any oversight mechanism or overarching North American integration process comparable to that in Europe (Clarkson 2008). Though the agreement provides for a dispute resolution mechanism, it is 
not intended as an appeal process for refugee claimants but rather as an avenue for both governments to resolve potential policy disputes. Both governments have so far resisted suggestions by the UNHCR and others to institute a mechanism for reviewing decisions made under the STCA. Moreover, while the STCA provides for regular monitoring of the agreement through the UNHCR, bilateral working groups and NGOs, these reviews are considered 'collaborations' and 'consultations' and thus not comparable to an independent, judicial oversight. ${ }^{37}$

\section{Shifting back up: the Designated Countries of Origin List}

In a similar manner to European governments, the Canadian government began designating certain countries as "safe" from December of 2012 onwards. While first designations have already elicited comments regarding the manufactured image of the "true" refugee that is emerging (no Latin American or African countries have been designated as of yet, in contrast to all European countries), ${ }^{38}$ more important for our purposes is the fact that these designations can be made solely by Ministerial Order, without public input. This is an indication that the Canadian government is returning to an old way of controlling migration policy - Executive discretion, which removes key migration control-related decisions from public and parliamentary scrutiny (Dauvergne 2005; Soennecken 2013a).

The Canadian criteria for designating a country as safe are somewhat broader than those used by EU member states and relate mainly to a country's democratic and human rights record, ${ }^{39}$ plus Canada also uses a set of quantitative indicators, which are based on a combination of rejection, withdrawal and abandonment rates of claims from this country before the IRB. A 60 to 75 percent rate can lead to a designation of a country as safe. ${ }^{40}$

While the adoption of the STCA and the DCO measures are indications that Canada's refugee policy has indeed taken a European turn, the procedural consequences for claimants who are designated as being from such a safe country more generally resemble the EU's accelerated policy regarding claims designated as "manifestly unfounded" in that they set up tight processing timelines, limit appeal mechanisms and speed up the removal process. Prior to the introduction of the DCO lists, this practice was only sporadically found in the Canadian system and was mainly applied to ineligible or already rejected claimants. 
Given the wide discrepancy of practices in EU member states and the disagreement over a common list at the EU level, plus the fact that the designation of various countries has also been challenged in domestic EU courts, this practice is problematic enough that it may be vulnerable to a court challenge in Canada as well. However, Canadian courts have generally tended to be quite deferential in assessing immigration policy partly because it involves reviewing administrative actions and partly because, historically, until the mid-196os, Canadian immigration law used to be protected against court challenges by a private clause (Soennecken 2013a).

\section{Conclusion}

To regain control over its refugee flows, Canada, after decades of delay, has finally joined the club of securitarian nations and in the process, become quite an eager student of the EU. In the process, it shifted policy "up," "down" and "out" as posited by the "venue shopping' explanation. For space reasons, only one, the "upwards" shift, was discussed here. Although we can observe similarities and even direct exchanges of ideas between Canada and the EU (notably between government bureaucrats at the transnational level), we should also underline a critical difference. The "upwards" shift in the Canadian case is quite distinct because power and control was deliberately shifted back "up" to the Executive, thereby returning Canada to the discretionary origins of its humanitarianism (Dauvergne 2005). As a recent review of the larger immigration and refugee policy changes has shown, the adoption and execution of the DCO provision is but one instance of a larger pattern of the Executive retaking control, away from Parliament or any venues that would remotely allow for any substantial degree of debate or discussion (Alboim \& Cohl October 2012).

While it may seem that the Canadian case also constitutes an example of an upwards shift to the intergovernmental level similar to that of the EU, the STCA agreement forged between Canada and the United States is bilateral and not part of a larger process of North American integration. As a result, it is unlikely to eventually come at a "price" similar to the recent empowerment of more human rights-friendly actors in the EU, such as the EU Parliament and the ECJ that arose through the ongoing transformation of the asylum policy field as part of the processes of EU integration. That said, the first instances of EU migration control coordination also started out at as similarly closed agreements with limited oversight mechanisms and little transparency regarding the process. Not only that, the evolution of 
the NAFTA and WTO dispute resolution mechanisms show that a transfer of authority to the international level can have domestic consequences for North American political actors as well, albeit decades later (Krikorian 2012). While the STCA dispute resolution mechanism is not likely to experience this kind of transformation any time soon, the consequences of the introduction of the long-delayed Refugee Appeals Division currently under way are far less certain.

At a macro level, this brief comparison has underlined that history and past policies matter. As shown by the gap between Canada's absorption by the securitarian club at the transnational level in the 1990s, the prior laying of the legislative groundwork for the adoption of the safe third country in 1988 and the forging of the STCA agreement in 2001, political actors cannot modify their institutional history and environment as they please, even if the overarching paradigm seems to have already shifted. They need to wait for a critical juncture to arise before they can do so (Guiraudon 2000: 258; Pierson 2000). Finally, although, it should already be clear from the preliminary analysis undertaken here that the recent Canadian changes are part of a larger, complex and multi-directional story of policy transfers between Canada, Europe and other "migration control" nations and not a simple case of uni-directional policy learning (Thouez \& Channac 2006), more work needs to be done to untangle the detailed workings of these growing transnational transfers. What ideas were considered but rejected? Which modifications did Canadian officials undertake in light of the European experiences? What opportunities exist to disrupt the transfer of such control-centred policies and eventually re-frame them? These are but some of the questions that should guide future analyses.

\section{Acknowledgements}

I would like to thank Sasha Baglay as well as the Journal's reviewers for their detailed comments, Rob Mauchel for his dedicated editorial assistance and Harald Bauder for his commitment to this special issue.

\section{Notes}

1. There are of course many definitions for this phenomenon. At its most basic, it is about placing national security over individual rights.

2. The Nansen medal is awarded annually to "a person or a group for outstanding work on behalf of the forcibly displaced," see http://www.unhcr.org/nansen/503743f86.html 
3. The Dublin "I" Convention was signed in 1990 by only a select number of EU countries (among them Germany) and came into force in 1997 (regulation 97/C 254/o). The Dublin ("II") Agreement - an EC Council Regulation, which replaced it and came into force in 2003 - is binding on all EU member states. Switzerland to Norway and Iceland have also joined.

4. For instance, Guiraudon has written about the growth of local and private (non-state) actors and on an increase in "remote control" policies in other regions. Although other works have detailed the expansion of inter- and transnational networks (e.g. Thouez and Channac, 2006), studies at the national level outside of Europe are limited (e.g. Garnier, 2010).

5. To "communitarize" something refers to exposing it to the "complete" EU decision-making machinery rather than keeping it at the intergovernmental level.

6. Three related directives that were also passed during this period are the 2001 Temporary Protection Directive, the 2003 Family Reunification Directive and the 2003 Third Country Nationals Directive.

7. The revised Qualification Directive was adopted in 2011. Its implementation deadline (Dec 21, 2013) is imminent. The Commission's 2008 "recast" of the Asylum Procedures Directive failed to be adopted in 2009 and was subsequently revised and re-presented on June 1, 2011. It was finally passed on June 26, 2013. The UK, Ireland and Denmark have opted out of these recasts. (For the UK and Ireland the previous versions will continue to apply). The revised 2008 Reception Conditions Directive was also re-presented in 2011 and equally passed on June 26, 2013. The Dublin "III" regulation was also passed on the same day, together with a revised EURODAC regulation, both will come into force on Jan 1, 2014, while the three new directives need to be transposed into national law within two years.

8. These views are well summarized on the website of the European Council for Refugees at www.ecre.org

9. A safe country is fundamentally one that adheres to the $195^{1}$ Geneva Convention for Refugees and the UN Convention against Torture, which all EU countries formally do. Although it does promise refugees more procedural rights, the new Dublin "III" regulation does not fundamentally alter the previous system and will even expand it to include those seeking subsidiary protection.

10. Only 4.1 percent of asylum seekers were actually transferred according to the 2007 EU Commission report (see Peers 2011). This was already considered an increase from earlier periods.

11. See www.ecre.org

12. EURODAC, a central database for fingerprints of asylum seekers, was initially set up in 2000.

13. Refugee advocates have generally been disappointed by the latest revisions because they have stepped away from earlier proposals, which would have raised some standards. For a summary, see Peers 2011 at www.statewatch.org and www.ecre.org .

14. Carrera, Hirshiand others vs. Italy, EUCtHR, 2012 and M.S.S. vs. Belgium and Greece, ECJ, 2011.

15. These are Council of European Communities resolutions from 1992 (Costello, 2005:40).

16. See, "Statewatch: EU divided over list of "safe countries of origin" - Statewatch calls for the list to be scrapped," Sept 2004, available at http://www.statewatch.org/analyses/no38-safe-countries.pdf

17. Belgium just amended its laws to re-introduce the notion of a safe country of origin in June 2012. The change became possible because of the 2005 EU Procedures Directive, which endorsed the possibility of safe country or origin lists.

18. See http://www.ecre.org/component/content/article/70-weekly-bulletin-articles/341-safecountries-of-origin-an-inconvenient-truth.html

19. In 2003: Canada's in-land acceptance rate stood at 49.6 percent and in 2006 , it was still at 47 percent. For 2011, it had dropped to 31.4 percent. See generally www.unhcr.org for statistics. 
20. The US, Canada and Australia provide over go percent of resettlements, while 16 EU make up about 8 percent, see UNHCR figures. Canada is particularly notable in this regard because such humanitarian admissions are factored into their overall, annual immigration planning,

21. The Canadian Council for Refugees recently showed that that the current overseas resettlement numbers are the second lowest in over 30 years. However 2010 legislation promised an increase of 500 spaces. The annual resettlement target was between 10,000 and 14,000 since the early 1990s. See http://ccrweb.ca/en/bulletin/13/03/07

22. Gezav. Canada (Minister of Citizenship and Immigration) (F.C.), 2004 FC 1039, [2005] 3 F.C.R. 3, discussed in Kernerman, 2008.

23. Jeffrey Simpson quoted in Soennecken, 2013b.

24. Canada did not officially have an accelerated procedure for manifestly unfounded refugee claims on the book by 2001. The only "expedited" procedure that did exist at the time was designed to speed up cases that clearly demonstrated a well-founded fear of persecution. This procedure has been on the books since 1993 although, lately, fewer and fewer cases have been processed using this avenue.

25. See www.actionplan.gc.ca

26. Macklin reports that between 1995 and 1997, Canada unsuccessfully tried to extend the agreement's applicability to inland claims but had to abandon the effort due to difficulties in establishing the travel patterns of would-be refugees (Macklin, 2005:372).

27. See http://www.cic.gc.ca/english/department/laws-policy/partnership/index.asp

28. Only a small number of claims are made at the U.S. border. See Canada, 2006: US chapter. Between 2000 and 2004, the U.S. reported an average of 58 claims annually. In return, Canada apparently agreed to resettle around 200 refugees a year chosen by the U.S. overseas (Macklin, 375).

29. Citizenship and Immigration Canada, A Partnershipfor Protection:Year One Review (CanadaUnited States Safe Third Country Review) Nov 2006, available at http://www.cic.gc.ca/ english/department/laws policy/partnership/chapter4.asp\#canada_c_1

30. Both the Canada-US STCA and the Dublin Convention make concessions based on family ties (although their status matters as well), and for unaccompanied minors. Technically, there are also 'public interest' and humanitarian exceptions in both, although they rarely apply. There is also an exception based on the status of the applicant; sometimes individuals who do not require a visa to enter Canada or even U.S. or Canadian citizens file an application for protection, see Arbel, 2013.

31. Arbel obtained additional figures directly from CBSA. For 2009, 763 and for 2010,761 and for 2011, 537 applicants were rejected based on the STCA, see Ibid.:7.

32. Canada, the US, and Europe all interpret 'family ties' differently. For instance, the U.S. does not include same sex partners in their definition, although this will change given the 2013 US Supreme Court ruling on the subject. The European definition of 'family' is limited to the nuclear family. The Canadian one is broader, including relatives ranging from grandparents to uncles.

33. Citizenship and Immigration Canada, "Notice - Measures for people affected by the lifting of the temporary suspension of removals to Burundi, Liberia and Rwanda," available at http:// www.cic.gc.ca/english/department/media/notices/notice-removal.asp

34. See www.cic.gc.ca/English/department/media/releases/2009/2009-07-23.asp

35. While most scholars argue that STCAs encourage irregular entry - something that is hard to quantify - it is even harder to quantify the number of individuals who do not leave their home country or apply for status.

36. The Federal Court of Canada initially invalidated the STCA in 2007 because the presiding judge agreed with arguments made by human rights organizations who do not consider the 
U.S. a "safe" country. He also criticized the government for not continually reviewing the agreement. The Federal Court of Appeal overturned this decision in 2008 rejecting both his constitutional and procedural arguments. The Supreme Court of Canada refused to hear the final resulting appeal. Canadian Councilfor Refugees $v$. Canada 2007 FC 161 and Canada v. Canadian Council for Refugees 2008 FCA 229.

37. See www.cic.gc.ca/English/department/laws-policy/partnership/chapter2.asp

38. Chile is the only exception, having been added to the list in May 2013. For the problem regarding the quantitative indicators, see Puddicombe, W. (2012). "You say my country is safe?! Designated countries of origin under the immigration and refugee protection act", Retrieved from http://refugeelawyers.net/3a_Puddicombe.pdf and for the choice of countries, see Liz, E. (2013). "Safe or unsafe: designated countries of origin". Retrieved from http://cynicsunlimited.com/2013/o2/28/safe-or-unsafe-designated-countries-of-origin/

39. The criteria used in most EU member states more explicitly check the risk of persecution in a given country following the 1951 Refugee Convention criteria, including protection against torture and inhumane treatment. For an overview of national practices, see the study by the British Institute of International and Comparative Law for the EU Commission available at http://ec.europa.eu/dgs/home-affairs/e-library/docs/pdf/safe_countries_2004_en_en.pdf. 40. http://www.cic.gc.ca/english/department/media/backgrounders/2012/2012-11-30.asp

\section{References}

Abell, N. A. (1997). Safe Country Provisions in Canada and in the European Union: A Critical Assessment. International Migration Review, 37 (3): 569-590.

Abu-Laban, Y. (1998). Welcome/STAY OUT: The Contradiction of Canadian Integration and Immigration Policies at the Millennium. Canadian Ethnic Studies, 20 (3): 190-211.

Alboim, N., \& Cohl, K. (October 2012). Shaping the Future:Canada's Rapidly Changing Immigration Policies. Toronto: Maytree Foundation.

Anderson, C. G. (2010). Restricting Rights, Losing Control: The Politics of Control over Asylum Seekers in Liberal-Democratic States - Lessons from the Canadian Case, 1951-1989. Canadian Journal of Political Science, 43 (4): 937-959.

Arbel, E. (2013). Shifting Borders and the Boundaries of Rights: Examining the Safe Third Country Agreement between Canada and the United States. International Journal of Refugee Law, 25 (1): forthcoming.

Brunet-Jailly, E. (2006). Security and Border Security Policies: Perimeter or Smart Border? A Comparison of the European Union and Canadian-American Border Security Regimes. Journal of Borderlands Studies, 21 (1): 3-21.

Canada, C. a. I. (2006).Canada-United States Safe Third Country Agreement Review:A Partnership for Protection, Year One Review.

Carrera, S., De Somer, M., \& Petkova, B. (2012). The Court of Justice of the European Union as a Fundamental Rights Tribunal: Challenges for the Effective Delivery of Fundamental Rights in the Area of Freedom, Security and Justice. CEPS Paper in Liberty and Security in Europe, No. 49 (August).

Clarkson, S. (2008). Does North America Exist? Governing the Continent After NAFTA and 9/11. Toronto: University of Toronto Press.

Costello, C. (2005). The Asylum Procedures Directive and the Proliferation of Safe Country Practices: Deterrence, Deflection and the Dismantling of International Protection? European journal of Migration and Law, 7: 35-69. 
Dauvergne, C. (2005). Humanitarianism, Identity and Nation: Migration Laws of Canada and Australia. Vancouver: UBC Press.

Dauvergne, C. (2008). Making People Illegal: What Globalization Means for Migration and Law. Cambridge: Cambridge University Press.

Dirks, G. E. (1995). Controversy and Complexity: Canadian Immigration Policy During the 1980 . Montreal, Kingston: McGill-Queen's University Press.

Dobrowolsky, A. (2011). The Intended and Unintended Effects of a New Immigration Strategy: Insights from Nova Scotia's Provincial Nominee Program. Studies in Political Economy, 87 (Spring): 109-142.

Forest, J. J. F. (Ed.) (2006). Homeland Security: Protecting America's Targets (Vol. 1), Westport, CT: Praeger.

Garnier, A. (2010). Are States in Control of their Borders? Testing the Venue-Shopping Approach in the Australian Context, Working Paper Series: Graduate Centre Humanities and Social Science of the Research Academy Leipzig.

Graziano, P., \& Vink, M. (Eds.). (2007). Europeanization: New Research Agendas Basingstoke: Palgrave

Guild, E. (2006). The Europeanisation of Europe's Asylum Policy. International Journal of Refugee Law, 18: 630-651.

Guiraudon, V. (2000). European Integration and Migration Policy: Vertical Policy-making as Venue Shopping. Journal of Common Market Studies, 38 (2): 251-271.

Guiraudon, V. (2001). Weak Weapons of the Weak? Transnational Mobilization around Migration in the European Union. In D. Imig \& S. Tarrow (Eds.), Contentious Europeans: Protest and Politics in an Emerging Polity. Lanham, Md.: Rowman and Littlefield.

Gurzu, A. (2012). Safe Country of Origin List at the EU Level: the Bargaining Process and the Implications. Journal of European and Russian Affairs, 7 (1): 1-14.

Irvine, J. A. S. (2011). Canadian Refugee Policy: Understanding the Role of International Bureaucratic Networks in Domestic Paradigm Change. In G. Skogstad (Ed.), Policy Paradigms, Transnationalism and Domestic Politics. Toronto: University of Toronto Press.

Jimenez, E., \& Crépeau, F. (2002). The Immigration and Refugee Protection Act. Horizons: Policy Research Initiative, 5 (2): 18-20.

Kaunert, C., \& Léonard, S. (2012). The Development of the EU Asylum Policy: Venue-Shopping in Perspective. Journal of European Public Policy, 19 (9): 1396-1413.

Kelley, N., \& Trebilcock, M. (1998). The Making of the Mosaic: a History of Canada's Immigration Policy. Toronto: University of Toronto Press.

Kernerman, G. (2008). Refugee Interdiction at Heaven's Gate. Government and Opposition, 43 (2): $230-248$.

Krikorian, J. D. (2012). International Trade Law and Domestic Policy: Canada, the United States and the WTO. Vancouver: UBC Press.

Lavenex, S. (1999). Safe Third Countries: Extending the EU Asylum and Immigration Policies to East and Central Europe. Budapest: Central European University Press.

Lavenex, S. (2001). The Europeanization of Refugee Policies: Normative Challenges and Institutional Legacies. Journal of Common Market Studies, 39 (5): 851-874.

Macklin, A. (2005). Disappearing Refugees: Reflections of the Canada-U.S. Safe Third Country Agreement. Columbia Human Rights Law Review, $36: 365-426$.

Moravcsik, A. (1998). The Choice for Europe: Social Purpose and State Power from Messina to Maastricht. Ithaca, NY: Cornell University Press.

Olsen, J. P. (2002). The Many Faces of Europeanization.Journal of Common Market Studies, 49 (5). Peers, S. (2011). EUJustice and Home Affairs Law (3rd ed.). Oxford: Oxford University Press. 
Pierson, P. (200o). Increasing Returns, Path Dependence, and the Study of Politics. American Political Science Review, 94 (2): 251-267.

Review, I. L. (1997). Not Just Numbers: A Canadian Framework for Future Immigration. Ottawa: Minister of Public Works and Government Services Canada.

Salter, M. B. (2007). Canadian Post 9/11 Border Security and Spillover Securitization: Smart, Safe, Sovereign? In M. Orsini \& M. Smith (Eds.), Critical Policy Studies. Vancouver: UBC Press.

Shachar, A. (2006). Race for Talent: Highly Skilled Migrants and Competitive Immigration Regimes. New York University Law Review, 81: 148-206.

Soennecken, D. (2013a). Extending Hospitality: History, Courts and the Executive. Studies in Law, Politics and Society, 6o: 85-109.

Soennecken, D. (2013b). The Managerialization of Refugee Determinations in Canada. Droit et Societé, 84 (2): 291-311.

Stoffman, D. (2002). Who Gets In: What's Wrong with Canada's Immigration Program - and How to Fix It. Toronto: Macfarlane Walter and Ross.

Thouez, C., \& Channac, F. (2006). Shaping International Migration Policy: The Role of Regional Consultative Processes. West European Politics, 29 (2): 370-387.

Varsanyi, M. W. (2008). Rescaling the "Alien," Rescaled Personhood: Neoliberalism, Immigration and the State. Annals of the Association of American Geographers, 98 (4): 877-896.

Watson, S. (2009). The Securitisation of Humanitiarian Migration: Digging Moats and Sinking Boats. London: Routledge.

\section{About the author}

Dagmar Soennecken, School of Public Policy \& Administration, York University. E-mail: dsoennec@yorku.ca

Dagmar Soennecken is an Assistant Professor in the School of Public Policy at York University. Her most recent publications include: "Germany and the Janus Face of Immigration Federalism: Devolution vs. Centralization,” in S. Baglay, D. Nakache, Immigration Regulation in Federal States: Challenges and Responses in Comparative Perspective (New York/Heidelberg, Springer, 2014) and "The Managerialization of Refugee Determinations in Canada," Droit et Société 84 (2013/2), 297-311.

\section{(1) $9 \Theta$}

2014 Soennecken / Amsterdam University Press.

This is an Open Access article distributed under the terms of the Creative Commons Attribution License (http:// creativecommons.org/licenses/by/2.o), which permits unrestricted use, distribution, and reproduction in any medium, provided the original work is properly cited. 